\title{
A Palestinian Growth History, 1968-2000
}

\author{
Sébastien Dessus \\ The World Bank
}

\begin{abstract}
The West Bank and Gaza have been occupied by Israel since 1967. As a result, it experienced a deep integration of its factor and goods markets with the richer economy of Israel. However, such an integration did not bring significant "dynamic" gains. Time series analysis indeed suggest that productivity growth hardly contributed to Palestinian GDP. Besides, the decomposition of income convergence patterns with Israel implies a rather unusual phenomenon of divergence in productivity. Economies of adaptation and scale that could have been encouraged by greater integration with Israel remained scarce, or were offset by opposite forces.
\end{abstract}

- JEL Classification: E13, F15, N15, O40

- Key words: West Bank and Gaza, Israel, total factor productivity, convergence

\section{Overview}

The West Bank and Gaza (WBG) have been occupied by Israel since 1967. As a result, the Palestinian economy experienced a deep integration of its factor and goods markets with the richer economy of Israel. Economic and population statistics remain highly uncertain, but there is little doubt that the Palestinian population benefited from a catch up phenomenon, whereby a small and developing economy is taking advantage of its "integration" with a larger and more developed one, at least in its early phase.

The nature of such an integration remains however unclear, as it might indeed

*Corresponding address: Sébastien Dessus, Sr. Economist, The World Bank UN-House, Riad El Solh P.O. Box 118577-Beirut 11072270 Lebanon, Tel: (961 1) 987800 ext. 225/Fax: (961 1) 986 800, E-mail: sdessus@worldbank.org (C2004-Center for International Economics, Sejong Institution, All Rights Reserved. 
theoretically lead to very different patterns. Naqib (2000) distinguishes two opposite set of theoretical effects of the integration between a large, advanced and rich economy with a small, poor and underdeveloped economy: "A favorable repercussion is an increased demand for the products of the small economy, a diffusion of technology and knowledge, as well as other spread effects, resulting from the geographical proximity to a large market leading to subcontracting, joint ventures and coordination in tourism and other services. ${ }^{1}$ Unfavorable repercussion arises from the disappearance of many industries in the small economy, its confinement to producing low-skill goods and the emigration of a sizeable segment of the labor force to the neighboring country, as well as to other countries." In the IsraeliPalestinian case, the fact that such an integration was imposed by one party to the other brings additional complexities, notably from an institutional point of view: on the one hand, Israel might have pursued economic policies that were not in the best interest of the Palestinian economy (Arnon and Weinbatt, 2000). ${ }^{2}$ On the other hand, the imposition of economic policies by Israel might have allowed Palestinian energies to concentrate on using market activities rather than the political system (through rent-seeking) to generate income, as observed in comparable cases (Schiff, 2002).

The empirical literature on the net impact of Israeli occupation remains also scarce. Valdivieso et al. (2001) notices that Total Factor Productivity (TFP) and capital stock growth in WBG (over the period 1973-94) compares well with Israel, suggesting positive transfers of technologies and convergence in capital stocks.

\footnotetext{
${ }^{1}$ Vamvakidis's (1998) results from a cross country analysis also suggest that North-South integration can boost GDP growth in the developing country, through economies of scale, technological spillovers, and reduced costs of adaptation and innovation.

${ }^{2}$ Between 1967 and 1994, the West Bank and Gaza was under the full control of the Israeli Authorities. Following the signature of the Declaration of Principles in 1993 by the Palestinian Liberation Organization and Israel, the Palestinian Authority (PA) was created, and granted some power on the Jericho Area and the Gaza Strip in 1994. Further transfers of powers (on geographical areas, to eventually gain jurisdiction of zones A and $\mathrm{B}$, representing some 30 percent of the West Bank and 60 percent of the Gaza Strip) and responsibilities (in policy-making) were progressively accomplished until end-1995. By early 1996, the PA became in charge of education, culture, tourism, welfare, statistics, energy, labor, local governments, agriculture and postal services among others. As far as "core" economic policy was concerned, the PA was granted on the other hand very little autonomy: the PA was denied the right to issue its own tender, thereby limiting the mandate of the Palestinian Monetary Authority (PMA) to the sole supervision of the banking system. Indirect taxes (VAT, import duties, purchase and excise taxes) were collected by the PA in WBG but continued to be set by Israeli authorities. Trade and industrial policies also continued to be largely driven by Israeli interests and political considerations (e.g. the absence of trade relationships with Arab League Members, but Jordan and Egypt; the creation of distribution monopolies in WBG to protect Israeli ones). The only significant leverage of economic policy granted to the PA was the control of its own public expenditures and the setting of direct taxes.
} 
But other authors rather suggest that the opened access of the Israeli labor market to a large and cheap Palestinian labor force was the main driving force explaining the observed convergence in per capita incomes since 1968 (Kleiman, 1999, Diwan and Shaban, 1999). The two phenomenon are not necessarily exclusive, but characterize very different models of development: in the former case, GDP growth is encouraged by innovation, competition and the development of productive capacities, notably for export markets; in the latter case, it is rather spurred by the demand for non-tradable goods, fuelled by workers remittances.

This paper aims at decomposing econometrically the determinants of GDP growth in West Bank and Gaza from 1968-2000, in order to isolate the contribution of TFP to GDP growth in WBG, and compare it with the same measure in Israel. In order to do so, we rely on statistics (population, employment, national accounts) collected before 1994 by the Israeli Central Bureau of Statistics (ICBS), and thereafter by the Palestinian Central Bureau of Statistics (PCBS) for West Bank and Gaza. ${ }^{3}$ As far as data on Israel are concerned (population, national accounts, total factor productivity), we rely on information provided by the Bank of Israel. The methodology consists in estimating a neo-classical Cobb-Douglas production function. This, within the framework of a generalized error-correction model, which permits to test co-integration relationships and to distinguish short term cyclical variations - believed to be significant in the Palestinian case, from longer run GDP response to capital accumulation. Different series of capital stock are built (using the perpetual inventory method with different initial capital/output ratio), and a sensitivity analysis is conducted on the impact of these initial conditions on results. Various other exogenous variables that might have influenced GDP in the short run are introduced to check the robustness of results. Based on econometric results, a TFP index is computed.

Results strongly suggest that TFP growth contributed only marginally to GDP growth since 1968: TFP grew on average by less than 0.5 percent every year over the period 1969-2000 (against 5.5 percent for GDP growth). Besides, the decomposition of income convergence patterns with Israel suggests a rather unusual phenomenon of divergence in productivity. In other words, Palestinian growth under occupation was transitional rather than sustainable, as mostly driven

${ }^{3}$ It is not entirely clear whether the two sources are strictly comparable in their coverage and respective methodologies. Besides, real economic aggregates for the period 1994-2000 were estimated by the World Bank, in the absence of national accounts in constant prices for this period. We nevertheless remain fairly confident on the overall reliability of such data. Besides, the econometric analysis restricted to the pre-1994 period gives very similar results. 
by factor accumulation. Conversely, technological transfers from Israel, economies of adaptation and innovation, and economies of scale that could have been encouraged greater integration with Israel extremely scarce since 1967 or were offset by opposite forces.

These results shed some interesting lights on the quality of growth in WBG since 1968 and it is hoped that this will help policy makers in their choices regarding future economic relations between the two parties. While the formal determination of causal relationships between GDP growth in WBG and the nature of integration with Israel goes beyond the scope of the paper, it nevertheless points to an important fact the lack of convergence in productivity between Israel and WBG-and suggests some avenues of research to better understand its causes.

The rest of the paper is organized as follows: Section II describes briefly the major phases of GDP growth in WBG since 1968. Section III presents and discusses the results of the econometric estimates; Section IV proceeds to a decomposition of income convergence patterns between Israel and the West Bank. Section V concludes with some remarks on the possible strategies to foster Palestinian GDP growth in the long run.

\section{Growth History, 1968-2000}

GDP growth in West Bank and Gaza was, first of all, characterized by its great volatility (see Figure 1). Over the period 1968-2000, the volatility of GDP growth, measured by the ratio of its standard deviation over its average, reaches a record of 1.4, a value comparable to the one of the most volatile economies of Latin America (IMF, 2001).

Several factors might probably explain this high volatility, from the bi-annual natural cycle of olive trees production to political events. ${ }^{4}$ Besides, such a high volatility most probably lowered average GDP growth, as volatility generally discourage savings and investment (Stiglitz, 1993). But this high volatility also renders difficult the calculation of an average growth rate, which would properly reflect the history of growth in West Bank and Gaza. In this regard, computing average GDP growth rates relying only on the information given by the first and last years of any given period is certainly not the most accurate methodology, as its

\footnotetext{
${ }^{4} \mathrm{~A}$ simple regression of the GDP growth rate on (i) the GDP growth rate in Israel, (ii) a dummy taking every two years the value 1 and the value 0 in between (so as to capture approximately the bi-annual cycle of olive production) and (iii) an index of internal and external closures (source: UNSCO) allows to explain 50 percent of GDP growth variation over the period 1969-2000.
} 
Figure 1. Real GDP growth, 1968-2000.

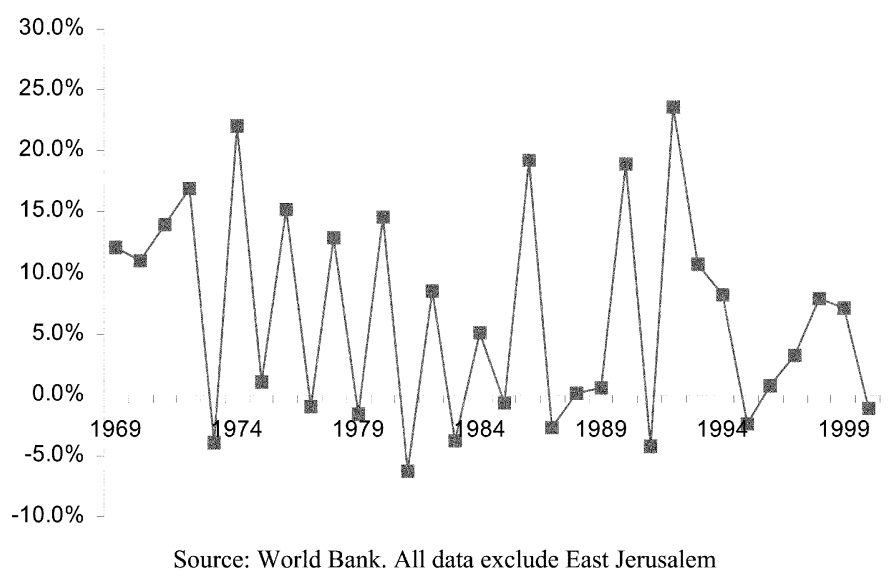

outcome dramatically depends on the period chosen. ${ }^{5}$ It is therefore advisable to use all the information contained during the period 1968-2000 to measure the average GDP growth rate in WBG. For this purpose, we simply estimate econometrically the following function:

$$
Y_{t}=A e^{\beta t}
$$

where $Y$ is the real GDP, $A$ an intercept, $t$ a linear trend and $\beta$ the average growth rate. Transformed with logarithms and estimated over the period 1968-2000 gives the following results (in parentheses are T-student statistics):

$$
\ln Y_{t}=-100.63+0.0546 t
$$

Adj. $\mathrm{R}^{2}=0.966 \mathrm{DW}=0.669$

In other words, the average annual GDP growth rate establishes itself at 5.5 percent (See Figure 2). Unless specified, all growth rates reported thereafter are computed econometrically.

Although the most accurate to reflect the average growth rate over the whole period, this estimate cannot obviously reflect the fact that GDP Growth went into several distinct episodes from 1968-2000. ${ }^{6}$ WBG experienced at first very rapid

\footnotetext{
${ }^{5} \mathrm{~A}$ simple illustration this fact is given by the following example. If calculated for the period 1970 to 1994, the average GDP growth rate establishes itself at 6.6 percent per year. But if one decals the interval by one year, that is, takes 1971 and 1995 as the two extremities of the new interval, then the average GDP growth rate goes down to 6.0 percent. A 0.6 percentage points difference might look marginal, but it is not: after 20 years, GDP levels differ by more than 10 percent with the two different growth rates.
}

${ }^{6}$ The following paragraphs rely extensively upon Diwan and Shaban (1999) and Kleiman (1999). 
Figure 2. Real GDP, 1968-2000.

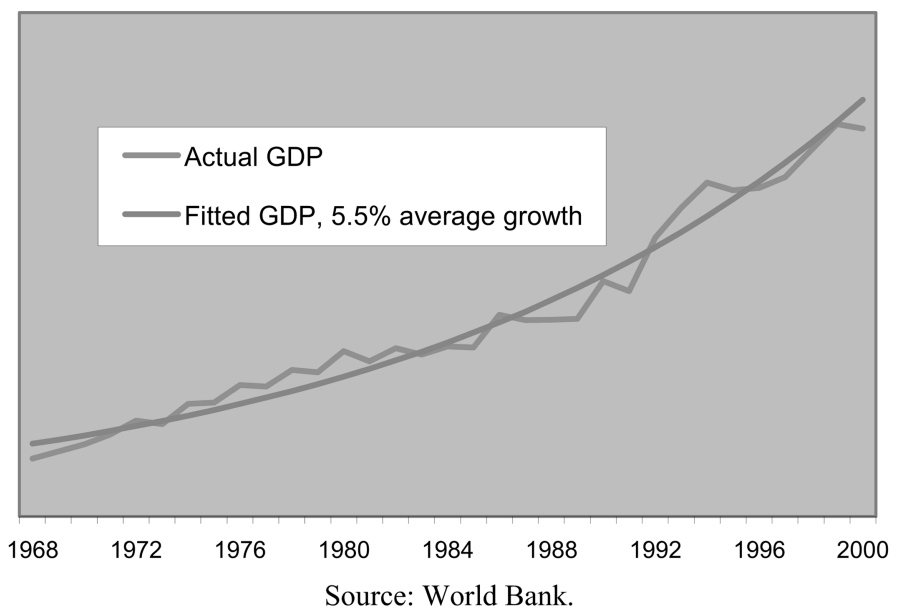

GDP growth in the years just following the 1967 war. The opening of the Israeli market to Palestinian labor, new trade and technological opportunities brought rapid growth in domestic production. Integration between the two economies was not perfect, as Israel imposed immediately barriers to the importation of Palestinian agricultural produce, and used administrative means to hamper the establishments of industrial firms in WBG which could compete with Israel. However, the initial income gap between the two economies was so large that their partial integration undoubtedly led to an income convergence phenomenon. The opened access of the Israeli labor market to a large and cheap Palestinian labor force was the main driving force explaining this phenomenon (Kleiman, 1999). Although mostly confined in unskilled activities, Palestinian workers were benefiting of larger and more modern productive capacities, hence receiving higher remuneration than in WBG. The share of Palestinian workers in Israel grew extremely rapidly, to reach approximately one-third in the early 70 s.

Once reached this level of labor market integration, GDP growth started to decline (from two to one-digit annual growth rates), as most of the wage gap had been narrowed. Furthermore, the 1973 war and the Oil crisis affected Israel negatively, and its demand for unskilled labor. But this negative shock was compensated by increased workers' remittances from Gulf Countries, which fueled domestic activity in WBG. In the early 80s, the collapse of the regional Oil boom prompted a decline in these remittances.

With the two main sources of growth (workers remittances from Israel and the Gulf) almost exhausted, WBG started to experience a stagnation of its domestic 
activity, which was operating under severe constraints. Diwan and Shaban (1999) identify four main constraints to GDP growth during the pre-Oslo period:

- Asymmetric market relations with Israel: while imports from Israel were unrestricted, Palestinian exports to Israel and the rest of the World were limited by the imposition of barriers to export in Israel, practical difficulties in trading across Israeli borders, inadequate infrastructure and the high degree of protectionism of the Israeli economy, which hampered trade creation with the rest of the world.

- Regulatory restrictions. Expansion of the private sector was held back by investment approvals required by Israel and uncertainty in legal and tax frameworks.

- Fiscal compression and institutional under-development. Fiscal compression and institutional under-development led to the under-provision of public goods. Low tax receipts, high fiscal leakages to Israel and the inability of municipalities to borrow limited public spending and the development of necessary infrastructure to the development of a modern Palestinian private sector.

- Restricted access to natural resources. Administrative limitations on water use from surface and aquifer reserves restricted the expansion of the agricultural and industrial sector.

The mounting impact of these constraints combined with reduced external resources probably triggered-inter alia - the first Intifada (Palestinian uprising against the occupation forces) in 1987, which in itself affected GDP negatively, as strikes, repression and uncertainty prevailed. ${ }^{7}$

Signed in 1994, the economic protocol of Oslo agreements-the Paris protocolaimed at lifting some of these constraints, by creating in WBG a political and economic environment more conducive to private investment and growth. Through substantial infrastructure investment, the creation of a tax revenue sharing mechanism between Israel and WBG, the elimination of lasting trade barriers in Israel for Palestinian agricultural products, the removal of restrictions on economic activities, reduced political and economic uncertainty associated with the phasing out of military occupation, the development of financial institutions, and the creation of a legal and regulatory framework, it was hoped to boost economic growth in the Palestinian economy.

However, the implementation of the Paris Protocol did not seem to have entailed

\footnotetext{
${ }^{7}$ The negative effect of the Intifada was partially compensated during its final years by the housing boom in Israel resulting from a surge in immigration, mainly from Russia. This boom was however temporary and accompanied with strong inflation in Israel and WBG.
} 
any structural break with respect to the pre-Oslo period, as far as GDP growth is concerned. The average GDP growth estimated above is not altered when the specification allows the growth rate to differ after $1994 .{ }^{8}$ Contrasting with what was considered in 1994 as positive steps to resume growth, the policy of internal and external closures ${ }^{9}$ imposed sporadically by Israel since 1995 certainly affected growth negatively, by increasing transaction costs and bringing additional uncertainty, thereby reducing incentives to invest in productive activities (Kanaan, 1998).

The period running from 1994 to 2000 is nevertheless too short to pronounce any definitive judgment on the impact on growth of the Oslo agreements. This period was also extremely erratic, with very distinct episodes mirroring the volatile evolution of political relationships with Israel, and in particular the degree of internal and external closures. In the initial post-Oslo years the economy experienced rapid growth with the return of nationals and large inflows of public and private capital, as the result of positive expectations on the peace process. But two years of intermittent external closures in 1995-96 precipitated the Palestinian economy in recession. From 1997 to September 2000, closures were less frequent, remittances from Palestinian workers in Israel fuelled demand for domestic products, transaction costs fell and private investment increased. The economy also benefited from an economic boom in Israel, which enhanced opportunities for exports of Palestinian labor and goods. The outbreak of the second Intifada in late September 2000 finally fractured the dynamics of economic recovery and once again demonstrated the negative impact of closure on economic growth.

As depicted in Figure 2, GDP was very close to its steady state growth path from 1997 to 1999, during which closures have been less prevalent than in 1995-96 and 2000. This might indicate that the general features of the Palestinian economy were not significantly modified by the Oslo agreements, with the notable exception of closures. Some suggestions can be advanced below to explain this fact, but testing them formally is rendered difficult given the small size sample of observations. Uncertainty (with regards to future political developments, but also

\footnotetext{
${ }^{8}$ One simple way to test this assumption is to add to the right-hand side of Equation (2) a multiplicative variable, $t *$ Oslo, with Oslo taking the value 0 before 1994, and 1 from 1994 to 2000. This multiplicative variable is not significantly different from zero at the 10 percent level, indicating no significant change in average growth after 1994.

9" Closure" is a term referring to the restrictions placed by Israel on the free movement of Palestinian goods and labor across borders and within the West Bank and Gaza. The restrictions take three basic forms: internal closure within the West Bank and Gaza, closure of the border between Israel and the West Bank and Gaza and closure of international crossings between the West Bank and Gaza and neighboring Jordan and Egypt.
} 
with regards to the existence and enforcement of rules and regulations) remained high after Oslo, and the implementation of a very complex system of permits to regulate trade did not help to reduce the already high levels of transaction costs (Sewell, 2001). Besides, some provisions of the Paris Protocol, such as monopolies, and the inadequacy of fiscal and trade to the best Palestinian interests policies might have actually also affect economic growth negatively in WBG (Arnon and Weinblatt, 2000). ${ }^{10}$ Finally, the continued high dependency on Israeli goods and labor markets did not allow the Palestinian private sector to diversify its risk, and entailed a significant and lasting trade diversion, whereby consumers and producers were encouraged to buy Israeli goods, in spite of the availability of cheaper goods on third markets. Expectations of finding a job in Israel stayed high as well, pulling up reservation wages in WBG and hence keeping wage-competitiveness at low levels. In turn, incentives to invest in order to expand and modernize productive activities might have not changed dramatically. This is illustrated by the fact that growth in capital stock (see below the discussion on capital stocks) did not significantly accelerate after Oslo, in spite of large amounts of official assistance provided by foreign donors. A second source of growth trade, through imports of technologies, increased competition and economies of scale on export markets remained also very asymmetric, with imports from Israel largely exceeding exports to Israel, as it was already the case before the signature of Oslo.

\section{Growth accounting}

A growth accounting exercise is of interest to measure the different source of long term growth in WBG. In particular, it allows to distinguish mechanically the contribution of factor accumulation to growth from the contribution of productivity growth (that is, a better use of existing productive capacities and the introduction of new technologies). ${ }^{11}$ In a neoclassical analytical framework ${ }^{12}$, it

\footnotetext{
${ }^{10}$ After 1994, most of economic policy decisions were still made in Israel, without consulting with the Palestinian authorities nor taking into account Palestinian interests. The Paris protocol did not include any effective mechanism to correct such an imbalance.

${ }^{11}$ This assumption of strict independence between factor accumulation and factor productivity is imposed for the sake of simplicity. In real life, it is nevertheless most likely that productivity affects factor accumulation, by influencing factors rate of return. Conversely, technological progress is often embodied in physical capital. See for instance Bradford de Long and Summers (1991), which find strong correlation between investment equipment and TFP growth.

${ }^{12}$ That is, assuming constant returns to scale and the remuneration of factors at their marginal productivity.
} 
corresponds to distinguishing transitional growth from long term potential growth, the latter being defined by the sole productivity growth, once returns to capital accumulation have been totally exhausted. Within this framework, accounting for growth simply consists in expressing per capita GDP growth, as the sum of (i) per capita capital stock growth multiplied by the elasticity of GDP with respect to capital and (ii) total factor productivity (TFP) growth, the latter being residually determined:

$$
\dot{y} / y=\alpha \dot{k} / k+\dot{x} / x
$$

where $y$ is real GDP per capita, $k$ the physical capital stock per capita, and $x$ the total factor productivity (TFP) level. The dot on top of a variable denotes the derivative of the variable with respect to time.

Practitioners generally face two major difficulties in the conduction of this exercise. First, the capital stock is generally unknown, and second, the elasticity of GDP with respect to capital is uncertain. Data on capital stock are generally obtained using the perpetual inventory method, which consists in cumulating investments over the years (accounting for some physical depreciation of the capital stock, generally at an annual rate of 4 to 7 percent), but this requires inevitably the identification of the capital stock level at one point in time. ${ }^{13}$ Different methods are used to identify such a capital stock, from the identification of steady state paths (Harberger, 1978), to the imposition of a pre-determined value in line with what has been estimated for other similar countries (IMF, 2001). The elasticity of GDP with respect to capital stock, $\alpha$, can theoretically be extracted from national accounts, as one minus the share of employees compensation on total GDP at factor cost, under the assumptions that (i) factors are remunerated at their marginal productivity, and (ii) that labor remuneration statistics encompasses all labor value-added. However, these two assumptions are not necessarily met, as market imperfections on the labor market, as well as under-accounting of real labor valueadded are frequently observed (Young, 1995).

To address these shortcomings, we proceed in this paper with a sensitivity analysis, which consists in (i) imposing arbitrary different initial values of capital stocks, and (ii), estimating econometrically Equation (3) to determine the elasticity of GDP with respect to the capital stock, $\alpha$. Results are then scrutinized

\footnotetext{
${ }^{13}$ The perpetual inventory method consists in writing the law of motion of capital $K_{t}$ as: $K_{t}=(1-\delta) K_{t-1}+I_{t}$, with $\delta$ the depreciation rate (fixed in this paper at 5 percent) and $I_{t}$ the flow of contemporaneous investment.
} 
Table 1. Production Function Estimates under Different Initial Capital Stocks, 1970-2000

\begin{tabular}{llllll}
\hline Initial k/y & \multicolumn{1}{c}{1.0} & 1.5 & \multicolumn{1}{c}{2.0} & \multicolumn{1}{c}{2.5} & \multicolumn{1}{c}{3.0} \\
\hline$\gamma$ & $3.050(3.78)$ & $2.496(3.78)$ & $2.043(3.82)$ & $1.660(3.80)$ & $1.320(3.47)$ \\
$\beta$ & $0.055(0.30)$ & $0.023(0.10)$ & $-0.006(0.02)$ & $-0.029(0.09)$ & $-0.043(0.12)$ \\
$\varphi$ & $-0.686(3.13)$ & $-0.614(2.94)$ & $-0.555(2.78)$ & $-0.507(2.66)$ & $-0.467(2.56)$ \\
$\varphi \alpha$ & $0.238(2.34)$ & $0.241(2.14)$ & $0.243(1.98)$ & $0.247(1.84)$ & $0.253(1.73)$ \\
Adj. R2 & 0.334 & 0.315 & 0.297 & 0.280 & 0.266 \\
Durbin Watson & 2.249 & 2.316 & 2.376 & 2.432 & 2.484 \\
$\alpha$ & 0.347 & 0.393 & 0.438 & 0.487 & 0.542
\end{tabular}

Average Annual Growth rates, 1970-2000

$\begin{array}{lccccc}\text { GDP per capita } & 2.21 \% & 2.21 \% & 2.21 \% & 2.21 \% & 2.21 \% \\ \text { Capital per capita } & 5.56 \% & 4.85 \% & 4.27 \% & 3.78 \% & 3.34 \% \\ \text { TFP } & 0.28 \% & 0.30 \% & 0.34 \% & 0.37 \% & 0.40 \% \\ \text { Observations } & 31 & 31 & 31 & 31 & 31\end{array}$

N.B. $y$ is GDP per capita; $k$ physical capital per capita. T-student statistics in absolute value are in parentheses. The initial $k / y$ (capital-output) ratio is computed for the year 1968. All reported growth rates are computed econometrically. Estimates are performed using instrumental variables for capital stock variables. The sample is restricted to the period 1970-2000 because of the use of lags.

against their economic plausibility and their econometric characteristics.

Table 1 reports the econometric estimates of a simple Cobb-Douglas function with constant returns to scale, ${ }^{14}$ under different assumptions for initial values of capital stock. The production function is estimated using an error correction model, so as to distinguish the short term impact of capital accumulation on GDP from its long term impact. It takes the form:

$$
\ln \left(y_{t} / y_{t-1}\right)=\gamma+\beta \ln \left(k_{t} / k_{t-1}\right)+\phi\left(\ln y_{t-1}-\alpha \ln k_{t-1}\right)
$$

In Equation (4), the $b$ coefficient gives the short term impact of capital accumulation on GDP, while a gives its long term impact. $f$, the error correction coefficient, measures at what pace the Palestinian economy corrects imbalances between its GDP and capital stocks levels, typically after a demand shock, and $g$ is an intercept. Equation (4) is estimated with instrumental variables for the capital stock in order to avoid simultaneity biases. ${ }^{15}$

\footnotetext{
${ }^{14}$ Wald tests cannot reject at the 10 percent level the null hypothesis of constant returns to scale in all 5 cases.

${ }^{15}$ The Hausman test of specification rejects at the 1 percent level the null hypothesis of exogeneity in all 5 cases. The instruments retained for these estimations are the World GDP, the Israeli GDP, a linear trend, a binary variable taking the value 1 the uneven years and 0 the even years, and the number of days of closures. The different capital stocks are regressed on these variables and their fitted values are introduced as exogenous variables to estimate equation (4).
} 
All parameters of interest have the expected sign, and are generally statistically different from zero at the 10 percent level. ${ }^{16}$ The elasticity of GDP with respect to capital, a, ranges between $1 / 3$ and $1 / 2$, which is in line with international standards but lower than the ratio of capital remuneration over GDP reported by the PCBS 3/ 5 in 1998. Unit root tests confirm the long-term nature of the relationship between value added and capital. ${ }^{17}$ On pure economic grounds, an elasticity of approximately 0.4 looks plausible. Labor costs (pulled by the access to the Israeli labor market) are high in WBG compared to capital (whose price is determined on international markets), and this might encourage producers to adopt capital-intensive technologies.

The lower the initial capital/GDP ratio, the better the quality of estimates, as measured with the $\mathrm{R}^{2}$ and T-students. The higher the initial capital/GDP ratio, the higher the elasticity of GDP with respect to capital. But whatever the assumption on capital stock is finally retained, results strongly suggest that total factor productivity growth contributed only marginally to GDP growth since $1970 .{ }^{18}$ Estimates are not sensitive to the initial capital/GDP ratio, and TFP growth over the period 1969-2000 lies in the interval comprised between 0.3 and 0.4 percent, which is a rather disappointing performance.

There are several potential explanations for slow TFP growth. First, most capital expenditures went to construction rather than productive activities, implying that only limited amounts of machinery and equipment were imported by investors to modernize and upgrade their activities since 1967. Data for 1998 indicate that investment expenditures devoted to building construction represented some four-fifths of total investment expenditures. Second, the manufacturing sector, where most productivity gains can potentially be achieved in the development process of a low- to middle-income economy, remained dormant. In economic

\footnotetext{
${ }^{16}$ These results are robust to the inclusion of variables describing potential short term shocks such as closures, business cycles in Israel, and cycles of olive trees productions. Under these alternative specifications, the lower the initial capital/GDP ratio, the better the quality of estimates. Adding a linear time trend to measure directly the average growth rate in TFP does not alter the results. The estimated coefficient of this trend is not significantly different from zero, suggesting that TFP growth has not been constant over the period of estimation.

${ }^{17}$ The per capita GDP and per capita capital series are all integrated of order 1: I(1)+T for GDP, I(1) for capital; and TFP series are all stationary: I(0). In other words, per capita GDP and per capita capital are co-integrated. Using a two steps approach, whereby the long term relationship is first estimated and its residual introduced in an error-correction model leads to the same results and conclusion.
}

${ }^{18}$ TFP growth is computed residually using Equation (3). 
development success stories such as Taiwan, for instance, sectoral reallocation of resources (especially labor) from agriculture to industry accounted for about half of the rapid total factor productivity growth (Dessus et al. 1995). In WBG, by contrast, most of the labor force was reallocated to services with generally low levels of labor productivity. Human capital, although rapidly accumulated by Palestinians, was not used to modernize productive capacities. Moreover, a large part of human capital remained unutilized due to the low labor force participation and high unemployment rates of skilled Palestinian women. Low returns to education pushed skilled male workers out of the Palestinian-Israeli labor market and encouraged migration to other markets (Angrist 1995). A Dutch disease phenomenon fueled by large inflows of income from abroad may have reduced the need for innovation and therefore productivity growth (Shafik 1997; Dutz and Hayri 2000; Astrup and Dessus 2002). The very low degree of Palestinian economic integration into global markets indicates-as a cause and/or a symptomits weak competitiveness and productivity. Finally, this observed low productivity growth suggests that Palestinian economic integration with Israel since 1967 has not benefited from significant technology transfers. This last issue is discussed in the following section.

\section{Convergence patterns}

While real GDP grew by 5.5 percent on average in West Bank and Gaza from 1968 to 2000 , it only grew by 4.2 percent in Israel ${ }^{19}$. During the same time, population grew by 2.9 percent in WBG and 2.4 percent in Israel. Therefore, per capita income convergence was observed between WBG and Israel: per capita GDP growth reached 2.6 percent a year in WBG, against 1.8 percent in Israel.

The observation of the evolution of the ratio of real GDP per capita in WBG over real GDP per capita in Israel nevertheless suggests that this catch up phenomenon was not uniform from 1968 to 2000. After a period of rapid convergence in GDP per capita (from 1968 to the mid-eighties) during which this ratio increased by about $50 \%$ (hence denoting a rapid narrowing in the income gap between Israel and West Bank and Gaza), per capita GDP tended to diverge from there onwards (See Figure 3). This figure does not indicate however the extent to which the per capita GDP gap between Palestinian and Israeli households was

\footnotetext{
${ }^{19}$ Data for Israel (GDP, GNP, population, total factor productivity) are from the Bank of Israel.
} 
Figure 3. Convergence in GNI and GDP per capita between WBG and Israel.

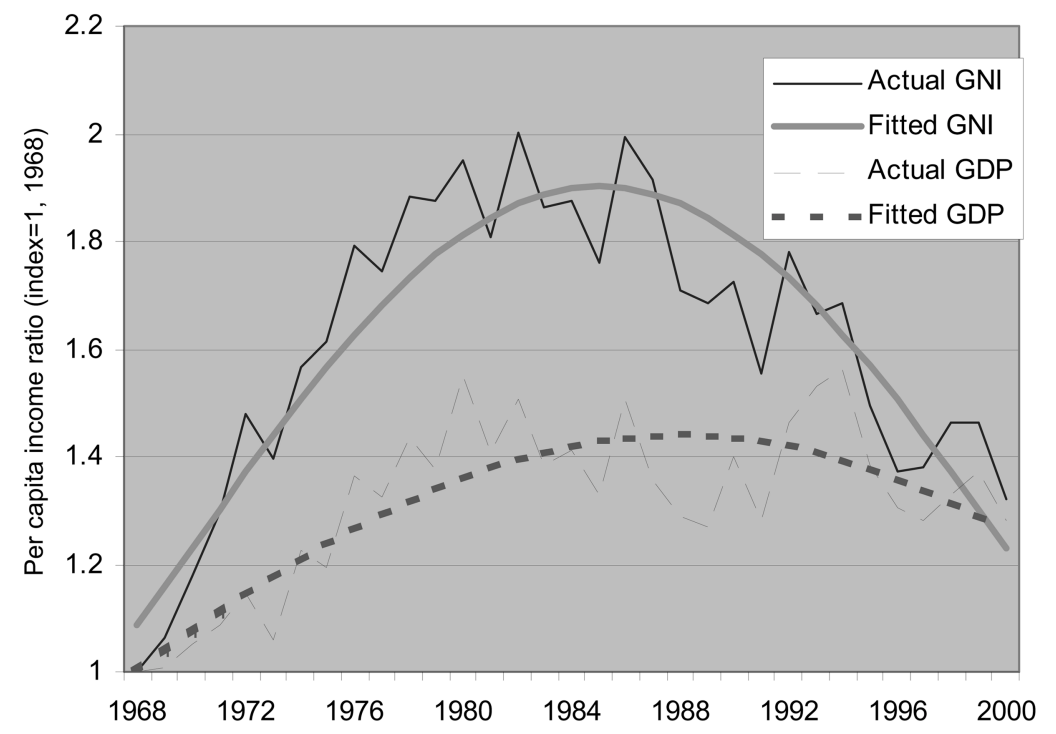

Source: Author's calculations based on ICBS and PCBS data. Note: the fitted lines are obtained by the regression on a time trend and a squared time trend of the logarithm of the ratio of real per capita GDP (respectively GNP) in WBG over real per capita GDP (respectively GNP) in Israel. Both the time trend and the squared time trend are significant at the 1 percent level, and the adjusted $\mathrm{R}^{2}$ is 0.700 (respectively 0.851 ).

reduced since 1967, as we use here per capita income indexes, rather than levels. There is indeed some uncertainties regarding the difference in per capita income levels between WBG and Israel at one point in time. This stems from the fact that, despite their close degree of economic integration, and an extensive use of the Israeli currency in the Palestinian economy, WBG and Israel might not necessarily face the same price levels. ${ }^{20}$ For the sake of illustration, had the per capita income gap (measured with per capita GDP at purchasing power parity) been of approximately 1:10 in 1968, as suggested by Naqib (2000), it would have declined to $1: 6$ in 1980 to come back to $1: 8$ in 2000 .

Income convergence phenomena, whereas the larger the initial gap in income (between two countries, or with respect to the steady state income of any given county) the faster the growth in income, are generally measured using statistics of

\footnotetext{
${ }^{20}$ Despite a close economic integration, the assumption that consumers in the WBG and Israel face the same prices for all goods and services may be rather strong. Most likely, Israeli prices are the upper level of prices for the WBG residents. Anecdotal evidence and theory suggest that the price level in the WBG may be lower than in Israel for non-tradable goods. On the other hand, the parallel movement in the price level of tradable goods in the WBG and Israel, supports the assumption that most consumer prices in Israel and the WBG are nearly the same (World Bank, 2000).
} 
GDP per capita (Barro and Sala-I-Martin, 1995). This, for the simple reason that the convergence phenomenon theoretically stems from the existence of decreasing returns in human and physical capital accumulation, as well as from the existence of a catch up phenomenon in productivity, ${ }^{21}$ which both influence GDP, and not GNP. ${ }^{22}$ Less attention, however, has been paid in the empirical literature on growth to the phenomenon of income convergence through the trade in production factors, and in particular through the export of labor services. This phenomenon might have had a significant impact in WBG, as export of labor to Israel grew very rapidly after 1967, and net factor incomes from abroad represent a very large share of total Palestinian income. ${ }^{23}$

From 1968 to 2000, real GNP per capita grew annually by more than 2.5 percent in WBG, against 2.1 percent in Israel. A convergence in income, measured with Gross National Income, might therefore be observed. But again, after a rapid convergence in incomes from 1968 to the mid-eighties, the income gap between WBG and Israel widened (See Figure 3).

Many factors are candidates to explain this pattern of convergence / divergence in incomes. Although high in some markets, the degree of economic integration between WBG and Israel has never been total, and varied over time (Naquib, 2000, Farsakh, 1998), as it will be discussed below. Besides, Palestinian and Israeli households might not necessarily have the same economic preferences, which for instance determine their savings rates, and the use and detention of different currencies. In this context, external shocks and policy making might have affected differently the income growth patterns of the two economies.

While acknowledging these differences, one striking feature of this patterns of convergence followed by divergence lies in the fact that the catch up phenomenon

\footnotetext{
${ }^{21}$ The theoretical principle for the convergence in productivity is similar to the one in factors accumulation. It simply assumes diminishing returns to imitation and adaptation of foreign technologies, which tends to generate a pattern of convergence: follower countries tend to grow faster the greater the technological gap from the leaders. ${ }^{22}$ The difference between GDP and GNP is given by net income from abroad, which does not directly
depend on capital stock and productivity levels in the economy.

${ }^{23}$ In 1998, Palestinian households (excluding East Jerusalem) received some US\$ 828 millions of net income from abroad, out of which US\$ 724 millions were from workers' remittances from Israel (Source: World Bank Staff calculations based on PCBS). This total amount represents an estimated share of 16.4 percent of GNP, which exceeds by far averages in the region or elsewhere. In the MENA region, this ratio did not exceed 1 percent in 1998, neither it did on average on average in the group of low \& middle income countries, nor in Egypt, Jordan or Lebanon (source: World Development Indicators).
} 
was more pronounced in GNP than in GDP (see Figure 3). Incomes, measured with GNP, converged, and then diverged, more rapidly than if measured with GDP. This would tend to suggest that workers remittances from Israel - by far the most important component of the difference between GDP and GNP, plaid a particular role in this regard. ${ }^{24} \mathrm{~A}$ simple calculation might help assessing the magnitude of this phenomenon. If one writes the per capita GNP, $\bar{y}_{i, t}$, of the country $i$ at the period $t$ like:

$$
\bar{y}_{i, t}=k_{i, t}^{\alpha_{i}} x_{i, t} z_{i, t}
$$

with $k$ the capital stock per capita, $x$ the level of TFP and $z$ the ratio of GNP over GDP. The income ratio between to economies $i$ and $j$ at the period $t$ can then be written, in logarithm like:

$$
\ln \left(\bar{y}_{i, t} / \bar{y}_{j, t}\right)=\ln \left(k_{i, t}^{\alpha_{i}} / k_{j, t}^{\alpha_{i}}\right)+\ln \left(x_{i, t} / x_{j, t}\right)+\ln \left(z_{i, t} / z_{j, t}\right)
$$

In turn, time-differentiating Equation (6) permits to decompose the change in income ratio as the sum of three components: (i) the evolution of the capital ratio between the two economies (a positive growth rate would denote a convergence in factor endowments between the two economies if country $i$ is initially the poorer), (ii) the evolution of the productivity ratio between the two economies (a positive growth rate would denote a convergence in productivity levels), and (iii) a residual term which capture the impact of net incomes from abroad on GNP.

This decomposition is applied to study the patterns of convergence/divergence between WBG and Israel. In order to do so, we use for WBG the results presented in Table 1, with an initial capital stock/GDP ratio of 2 in 1968. For Israel, the TFP series is extracted from the Bank of Israel (BoI), and the contribution of capital to GDP is obtained by the difference between logarithms of GDP per capita and TFP.

Table 2 reports such a decomposition of the convergence patterns over different periods. 1985 is chosen as a pivotal year, as it marks approximately the year where incomes started to diverge (cf. Figure 3). This table first reveals that, over the whole period, per capita GNP grew each year 0.4 percent more rapidly in WBG than in Israel. It also permits to observe that this convergence in incomes was

\footnotetext{
${ }^{24}$ The other mechanical explanation for the difference in convergence/divergence patterns measured with GDP and GNP could stem from the fact that GDP and GNP growth also widely differed in Israel. But it appears that the ratio of GNP/GDP has been much more stable in Israel than in WBG between 1968 and 2000: the volatility of this ratio, measured by the standard deviation over its average is $3.8 \%$ in Israel and $8.1 \%$ in WBG.
} 
Table 2. Income convergence and divergence patterns between WBG and Israel

\begin{tabular}{lccc}
\hline & $1968-2000$ & $1968-1985$ & $1986-2000$ \\
\hline Net Convergence effect & $0.39 \%$ & $3.54 \%$ & $-2.46 \%$ \\
Capital & $1.45 \%$ & $2.63 \%$ & $0.19 \%$ \\
Productivity & $-0.71 \%$ & $-0.30 \%$ & $-0.51 \%$ \\
Income from abroad & $-0.35 \%$ & $1.20 \%$ & $-2.15 \%$ \\
\hline
\end{tabular}

Source: Author's calculation based on PCBS and BoI. Growth rates are obtained by regressing the logarithm of the considered variable over a time trend. For that reason, growth rates of sub-periods do not necessarily add up.

mainly due to a more rapid capital accumulation in WBG than in Israel (1.4 percent higher every year in WBG). Conversely, one can observe throughout the period a phenomenon of divergence in productivity: on average each year, from 1968 to 2000, productivity grew by 0.7 percent more rapidly in Israel than in WBG. Table 2 also indicates that the structural break observed in the mid-eighties can mostly be explained by the dramatic drop in Palestinian incomes from abroad compared to Israel. This, most likely as a result of the return of Palestinian skilled workers from the Gulf from the 80s onwards, and the decline of the share of Palestinian workers commuting to Israel after $1987 .{ }^{25}$

The analysis therefore suggests that the de facto economic integration of West Bank and Gaza with Israel has not produced the positive dynamic gains - notably in terms of productivity growth and technological transfers, that could have been theoretically expected. Would have the net outcome of integration been better with greater and more stable integration ? And in particular, would have the catch up in productivity been more rapid under such conditions ? A last set of regressions sheds some light on this issue. According to typical technological leader-follower model, the catch-up in productivity phenomenon may be specified like:

$$
\dot{x}_{i} / x_{i}=\phi\left(x_{j} / x_{i}, w\right), \phi^{\prime}>0, \phi^{\prime \prime \prime}<0, \phi(1,1)=0
$$

where $w$ is an index of integration ranging from 0 to 1 between countries $i$ and $j$ and $x$ the TFP level. In non-mathematical terms, Equation (7) describes the fact that, under assumptions of diminishing returns to education and adaptation of foreign technologies, follower countries (in this case, West Bank and Gaza, country $i$ ), tend to grow faster the greater the technological gap from the leaders

\footnotetext{
${ }^{25}$ The percentage of the Palestinian labor force working in Israel grew up to 35-40 percent in the mid eighties (with a maximum of 38 percent in 1987), before dropping to about $15-20$ percent by the end of the century (Farsakh, 1998).
} 
(in this case, Israel, country $j$ ). However, it is most likely that being backward does not in itself guarantee that the economy will catch up. This is probably conditional, inter alia, on the degree and nature of exchanges between the two countries (Pissarides, 1997). Therefore, the catch-up phenomenon will also be conditioned by the degree of integration between the two economies.

In its simplest form, Equation (7) can be estimated like:

$$
\dot{x}_{i} / x_{i}=\lambda\left(x_{j} / x_{i}\right)+\mu w
$$

with $\lambda$ the speed of convergence in productivity, once controlled for the degree of integration between the two economies. This specification requires to know at one point in time the gap in TFP levels between WBG and Israel, which is rendered difficult by the fact that data on purchasing power parities are not available. To overcome the obstacle, we write $x_{j, 0}$ the initial TFP level in Israel as a multiplicative factor of the initial level of TFP in WBG:

$$
x_{j, 0}=A x_{i, 0}
$$

and combining (7) and (8) gives after some algebra (with $g_{i, t}$ the TFP growth rate in country $i$ at the period $t$ ):

$$
g_{i, t}=\lambda A \prod_{k=1}^{t-1}\left[\frac{1+g_{j, k}}{1+g_{i, k}}\right]+\mu w_{t}
$$

This equation can be directly estimated, as it only embodies TFP growth rates. However, such estimate does not allow to separate $\lambda$ from $A$, and therefore identify these two parameters. Only their product can be estimated. As far as the degree of integration between the two economies, $w$, is concerned, we use the (logarithm of the) wage differential between Palestinian workers employed in Israel and in $\mathrm{WBG}^{26}$ The lower the differential (zero in case of wage equalization), the higher the degree of integration. We believe that this indicator is a fair indicator of integration between the two economies, as labor market integration is generally perceived as a higher step of integration than goods market integration.

Results obtained estimating Equation (10) suggest that a catch up phenomenon might have indeed been associated after 1968, as the coefficient associated with $\pi$, the multiplicative term, is statistically different from zero and positive (T-student

\footnotetext{
${ }^{26}$ Source: Arnon, Spivak and Weinblatt (1997) and PCBS labor force surveys, various issues. In the early eighties, Israeli and Palestinian labor markets were highly integrated, as illustrated by wage differentials close to zero between Palestinian workers in Israel and WBG.
} 
statistics are in parenthesis).

$$
\begin{array}{rlrl}
g_{i, t}= & 15.568+0.877 \pi_{t}-0.025 w_{t}-0.008 t \\
(5.95) \quad(5.06) \quad(0.42) \quad(6.04) \quad \text { Adj. } \mathrm{R}^{2}=0.435 \quad \mathrm{DW}=2.122
\end{array}
$$

But this phenomenon was not strong enough to offset some other negative factors, here captured by a linear trend, $t$. Surprisingly, the degree of market integration does not seem to have plaid a significant role. ${ }^{27}$ Or, in other words, is not a sufficient candidate to explain the observed patterns of divergence in Total Factor Productivity.

Some other explanation must be found, although it goes beyond the scope of this paper. We just suggest here some possible ways of future research. One could possibly be the lack of technological diffusion capacities (institutions) within the West Bank; another one could be that the incentive structure in place in WBG since 1968 did not encourage the adaptation and use of foreign technologies, in a macro-economic context where non-tradable activities - in which the demand for new technologies is usually lower than in tradable activities, were encouraged (Astrup and Dessus, 2002).

But more generally, this result calls for some additional thinking on why integration does not always promote TFP growth. We suggest here an explanation, or at least some preliminary theoretical framework, under which this question could be approached. The nature of integration may be characterized according to three criteria, which all have an impact on growth and convergence patterns: (i) the degree of trade integration; (ii) the degree of labor market integration, and (iii) the availability of macro-economic instruments (fiscal, monetary, exchange rate policies), to correct imbalances. Trade integration most likely promotes technological convergence; on the other hand, labor market integration, ceteris paribus, might favor the over-valuation of the real exchange rate in the poorest country, thereby distorting the incentive structure and reducing the demand for foreign technologies. One way to correct for such a negative outcome of (labor market) integration is to adjust the exchange rate accordingly.

The European Union represents a successful case of integration: Spain, Portugal and Ireland clearly benefited from a productivity catch-up phenomenon with the

\footnotetext{
${ }^{27}$ Various tests were conducted to confirm this result. In particular, various lagged structure were used to capture potential delays in adjustment to a new degree of integration; Hausman tests of exogeneity were also conducted, using different subsets of instruments. None of these tests allowed to question the conclusion put forward in the text.
} 
richer economies of France and Germany. In this case, trade was liberalized, while labor markets remained poorly integrated; and countries had some policy autonomy to correct imbalances. Italy, where the South, despite pro-active public policies, has been unable to catch up rapidly with the North, is an intermediate case, whereby trade and labor markets were integrated, but no policy tools were available to correct imbalances. Finally, the Israeli-Palestinian type of integration possibly represents a case with all defaults: high degree of labor market integration; low degree of trade integration; no policy tools available to correct imbalances. Notwithstanding the fact that there was no shared will of integration, this pattern of integration probably explains to a significant extent the poor outcome of the Israeli occupation.

\section{Conclusion}

GDP growth is a complex phenomenon. It is probably driven in the long run by supply-side conditions, i.e., the change in the level of productive capacities (labor, human and physical capital, the technology), and in the shorter run by demand conditions, which will affect the utilization rate of these capacities, and determine their growth paths. In West Bank and Gaza, like everywhere else, this is a combination of domestic and external factors and policies which determine growth, and one should obviously not focus only on the nature of relation with Israel to explain past growth and predict future Palestinian growth. Nevertheless, it remains obviously a conditioning factor, as the capacity for Palestinian authorities of making decision of economic and institutional nature depends on their degree of autonomy in these fields. Therefore, the nature of economic relation with Israel not only affects the environment in which the Palestinian economy is evolving, but also the spectrum of policy instruments at the disposal of Palestinian authorities to promote growth.

The observation of growth patterns for the period 1968-2000 suggests that growth in WBG was mainly fuelled by factor accumulation. Conversely, productivity growth contributed only marginally to GDP growth all over the period of occupation, and Oslo agreements did not radically changed the situation. This tends to indicate that the forced integration of WBG with Israel did not bring the dynamic gains that could have been expected, notably in terms of transfers of technology and greater access to export markets. The degree of integration between the two economies, although highly variable during the period, cannot 
simply explain this weak performance. Therefore, lifting the restrictions on the movement of Palestinian people and goods between WBG and Israel - while certainly helpful and necessary to restore minimum income levels ${ }^{28}$ - is probably not sufficient to foster domestic growth in a sustainable manner.

Two alternative ways of development might therefore be envisaged. A first one, in which decision makers will try to maximize the benefits of integration which have been observed in other parts of the world (e.g. following the creation of the European Union). This might notably necessitates implementing measures to (i) encourage Israeli investments (public and private) in West Bank and Gaza; (ii) facilitate the transfer of Israeli technologies to WBG; (iii) reduce barriers to access to higher positions for Palestinian workers in Israel; (iv) reduce transaction costs to favor trade integration. Several measures had been initiated in this regard during the Oslo period, like the development of industrial estates to promote Israeli Palestinian private joint ventures, but much remained to do in this domain as well as in all the other above-mentioned domains.

A second way of development would consist in eliminating the current negative aspects of integration by dis-integrating the two economies. This would at least require to grant greater autonomy to the Palestinian authorities in their decision making, and provide them with the physical (trade infrastructure) and legal means (trade policies) to maximize the gains of a more direct integration into world markets.

\section{Acknowledgments}

The author would like to thank Enisse Kharoubi, Elizabeth Ruppert-Bulmer, Paolo Zacchia and two anonymous referees for their suggestions and comments. The views expressed here are those of the author and do not necessarily reflect those of the World Bank, its Executive Directors or the country they represent. Usual disclaimers apply.

Received 7 July 2003, Accepted 10 August 2004

\footnotetext{
${ }^{28}$ See World Bank (2002) for a detailed description of the economic and social impact of the second Intifada.
} 


\section{References}

Angrist, J. (1995), "The Economic Returns to Schooling in the West Bank and Gaza Strip,", The American Economic Review, 85: 1065-87.

Arnon, A., A. Spivak and J. Weinblatt (1997), The Palestinian Economy: Between Imposed Integration and Voluntary Separation, Leiden, Brill.

Arnon, A. and J. Weinblatt (2000), Sovereignty and Economic Development: The Case of Israel and Palestine, Ben-Gurion University of the Negev, Israel. Photocopied.

Astrup C. and S. Dessus (2002), Exporting Goods or Labor ? long term implications for the Palestinian Economy, MENA Working Paper Series, 29, The World Bank, Washington.

Barro, R.J. and X. Sala-I-Martin (1995), Economic Growth, McGraw-Hill, New York.

Bradford de Long, J. and L. Summers (1991), "How Strongly Do Developing Countries Benefit from Equipment Investment?," J. Bradford de Long's Working Papers 108, University of California, Berkeley.

Dessus, S., J.D. Shea, and M.S. Shi (1995), Chinese Taipei: The Origins of the Economic "Miracle", Development Centre Studies, Organisation for Economic Co-operation and Development, Paris.

Diwan, I. and R. Shaban (1999), Development Under Adversity: The Palestinian Economy in Transition, MAS and the World Bank, Washington D.C.

Dutz, M. and A. Hayri (2000), "Does More Intense Competition Lead to Higher Growth?," Policy Research Working Paper, 2320, The World Bank, Washington D.C.

Farsakh, L. (1998), Palestinian Employment in Israel: 1967-1997, A Review, Palestine Economic Policy Research Institute (MAS), Ramallah.

Harberger, A. (1978), "Perspectives on Capital and Technology in Less-Developed Countries," in M.J Artis, and A.R. Nobay, (eds.), Contemporary Economic Analysis, Croom Helm.

International Monetary Fund (2001), West Bank and Gaza: Economic Performance, Prospects and Policies, Middle Eastern Department, Washington D.C.

Kanaan, O. 1998. "Private Investment Under Uncertainty in the West Bank and Gaza Strip," in The Economy of the West Bank and Gaza Strip, Middle Eastern Department, International Monetary Fund, Washington.

Kleiman, E. (1999), "Fiscal Separation with Economic Integration: Israel and the Palestinian Authority," in A. Razin and E. Sadka (eds.), The Economics of Globalization, Cambridge University Press: Cambridge.

Naqib, F.M. (2000), Economic Relations Between Palestine and Israel During the Occupation Era and the Period of Limited Self-Rule, Working Paper 2015, Economic Research Forum for the Arab Countries, Iran and Turkey, Cairo.

Pissarides C. (1997), "Learning by Trading and the Returns to Human Capital in Developing Countries," World Bank Economic Review, 11(1): 17-32.

Schiff, M. (2002), Trade Policy and Labor Services: Final Status Options for the West 
Bank and Gaza, Policy Research Working Paper 2824, The World Bank, Washington D.C.

Sewell, D. 2001. "Governance and the Business Environment in West Bank/Gaza," MENA Working Paper Series, 23, The World Bank, Washington D.C.

Shafik, N. (1997), "Rents, Reforms and Economic Malaise in the Middle East and North Africa," Research in the Middle East Economics, 2: 221-45.

Stiglitz, J.E. (1993), "Endogenous Growth and Cycles," National Bureau of Economic Research Working Paper, 4286, March, Cambridge.

Valdivieso, R., U. Erikson von Allmen, G. Bannister, H. Davoodi, F. Fischer, E. Jenkner and M. Said. 2001. West Bank and Gaza Economic Performance, Prospects, and Policies: Achieving Prosperity and Confronting Demographic Challenges, Middle Eastern Department, International Monetary Fund: Washington, D.C.

Vamvakidis, A. (1998), "Regional Integration and Economic Growth," World Bank Economic Review, 12(2): 251-270.

World Bank (2000), "Poverty in West Bank and Gaza," West Bank and Gaza Update, April, Al-Ram.

World Bank (2002), 15-month Intifada, Closures and the Palestinian Economic Crisis: an Assessment, Washington D.C.

Young, A. (1995), "The Tyranny of Numbers: Confronting the Statistical Realities of the East Asian Experience," Quarterly Journal of Economics, 110, August, 641-679. 